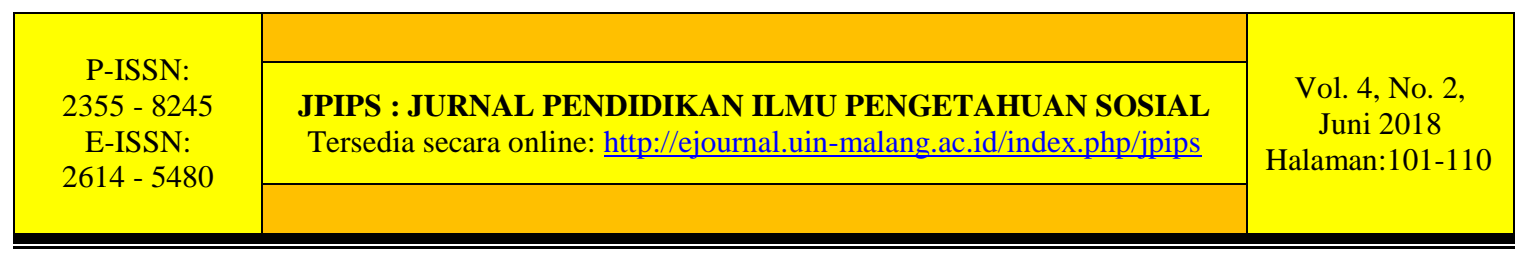

\title{
PENGEMBANGAN MEDIA PEMBELAJARAN ULAR TANGGA UNTUK MENINGKATKAN MOTIVASI BELAJAR SISWA KELAS VIII MATA PELAJARAN IPS DI SMP MUHAMMADIYAH 15 LAMONGAN
}

\author{
Dewi Ayu Imaliyah \\ Universitas Islam Negeri Maulana Malik Ibrahim Malang \\ dewiayu@gmail.com
}

\begin{abstract}
Abstrak: Problematika yang terjadi di SMP Muhammadiyah 15 Lamongan yakni peserta didik merasa jenuh dengan metode pembelajaran ceramah dari para guru tanpa melibatkan siswa untuk berperan aktif dalam pembelajaran. Hal ini disebabkan karena guru lebih aktif di kelas dengan menggunakan metode pembelajaran ceramah dan media pembelajaran LKS. Hal ini bisa mengurangi kreativitas siswa dalam berekspresi. Tujuan penelitian ini adalah untuk : (1) mengembangkan media pembelajaran Ular Tangga mata pelajaran IPS kelas VIII SMP Muhammadiyah 15 Lamongan, (2) mengetahui kelayakan media pembelajaran Ular Tangga mata pelajaran IPS untuk siswa kelas VIII SMP Muhammadiyah 15 Lamongan berdasarkan penilaian dari ahli materi dan ahli media, (3) memberikan perbedaan peningkatan motivasi belajar kelas eksperimen dan non eksperimen dalam penggunaan media ular tangga di SMP Muhammadiyah 15 Lamongan. Skripsi ini menggunakan pendekatan penelitian Research and Development (R\&D) dengan model pengembangan ADDIE (Analysis, Design, Development, Implementation. Evaluation). Hasil penelitiannya adalah (1) Peneliti melakukan uji coba lapangan dilakukan kepada 15 siswa dalam kelompok eksperimen kelas VIII SMP Muhammadiyah 15 Lamongan. Prototype yang dilakukan uji coba lapangan mendapat presentase $87 \%$ sehingga dikonverensikan berada pada tingkat kualifikasi valid. (2) Kelayakan aspek rekayasa media dari 21 pernyataan termasuk kategori layak. Penilaian dari dosen adalah $75 \%$ cukup menarik tingkat validitas dapat digunakan dengan revisi kecil. Dengan demikian media ular tangga dalam penilaian ahli media layak digunakan sebagai media pembelajaran siswa SMP. (3) Media pembelajaran media ular tangga pada materi perubahan masyarakat Indonesia pada masa penjajahan dan tumbuhnya semangat kebangsaan secara efektif dapat meningkatkan hasil belajar siswa kelas VIII SMP Muhammadiyah 15 Lamongan. Dengan melihat rata - rata kelas kontrol lebih kecil dibandingkan dengan kelas eksperimen pada post-test yaitu $1262<1355$.
\end{abstract}

\section{Kata Kunci: pengembangan, ular tangga, media pembelajaran}

Abstract: The problems that occurred in Junior High School Muhammadiyah 15 Lamongan is learners feel saturated with teaching methods of lectures from teachers without involving students to take an active role in learning. The students still lack creativity in learning IPS materials. This is because teachers are more active in the classroom by using lecture learning methods and learning media LKS. The purpose of this research is to: (1) to develop learning media of Snake Ladder social education subjects VIII grade Junior High School Muhammadiyah 15 Lamongan, (2) to know the feasibility of learning media Snake Ladder IPS subjects for grade VIII Junior High 
School Muhammadiyah 15 Lamongan students assessment of material experts and media experts. This thesis uses a research and development approach or Research and Development $(R \& D)$ with the development model of ADDIE (Analysis, Design, Development, Implementation Evaluation. The result of the research is (1) The researcher conducting field trials conducted to 15 students in the experimental group class VIII Junior High School Muhammadiyah 15 Lamongan. The field trial prototype gets an $87 \%$ percentage so that it is converted to a valid qualification level. (2) The feasibility of the media engineering aspects of the 21 statements is categorized as feasible. Assessment of the lecturer is $75 \%$ interesting enough the level of validity can be used with small revisions. Thus media ladder snakes in the assessment of media experts worthy of use as a medium of learning junior high school students. (3) Media learning snake ladder on the material changes in Indonesian society during the colonial period and the growth of nationalism spirit can effectively improve the learning outcomes of students of class VIII SMP Muhammadiyah 15 Lamongan. By looking at the average control class is smaller than the experimental class on the post-test that is $1262<1355$.

Keywords: development learning, snake ladder, learning media

\section{PENDAHULUAN}

Penggunaan media pembelajaran sangat penting dalam proses belajar dan mengajar. Hal ini karena media pembelajaran sangat membantu guru atau pengajar dalam memberikan pengajaran secara maksimal, efektif, dan efisien. Pembelajaran merupakan sebuah sistem karena di dalamnya memiliki komponen-komponen yang saling berkaitan dalam rangka mencapai tujuan yang ditentukan. Komponen tersebut terdiri atas tujuan, materi, metode, media, dan evaluasi. Masing-masing komponen tersebut saling berkaitan dan merupakan satu kesatuan yang tidak terpisahkan.

Media pembelajaran merupakan suatu teknologi pembawa pesan yang dapat digunakan untuk keperluan pembelajaran; media pembelajaran merupakan sarana fisik untuk menyampaikan materi pelajaran. Media pembelajaran merupakan sarana komunikasi dalam bentuk cetak maupun pandang dengar termasuk teknologi perangkat keras. Agar efektivitas pembelajaran dapat tercapai, maka diperlukan media yang mempunyai kemampuan mendorong siswa untuk melibatkan siswa dalam proses pembelajaran secara aktif, (Rusman, 2012). Salah satu fungsi utama media pembelajaran adalah sebagai alat bantu mengajar yang turut mempengaruhi iklim, kondisi, dan lingkungan belajar yang ditata dan diciptakan oleh guru, (Azhar, 2002). Guru harus menggunakan media yang terbaik untuk memfasilitasi pembelajaran atau meingkatkan pemahaman siswa terhadap materi pengajaran. Dengan demikian, melalui penggunaan media pembelajaran, diharapkan siswa akan lebih mudah dalam memahami materi yang disampaikan oleh guru.

Problematika yang terjadi di SMP Muhammadiyah 15 Lamongan yakni peserta didik merasa jenuh dengan metode yang hanya cenderung ceramah saja dan sarana prasarana yang belum merata ditiap kelas ditambah lagi pelatihan penerapan kurikulum 2013 yang minim dilakukan dikelas. Salah satu aspek penilaian dalam kurikulum 2013 adalah aspek keterampilan. Dalam penelitian ini siswa SMP Muhammadiyah 15 Lamongan masih minim kreativitas dalam pembelajaran materi IPS. Hal ini disebabkan karena guru lebih aktif di kelas dengan menggunakan metode pembelajaran ceramah dan media pembelajaran LKS. Hal ini bisa mengurangi kreativitas siswa dalam 
berekspresi, karena materi IPS lebih kepada menghafal yang mana siswa dituntut untuk memahami materi dengan cara yang bermacam-macam sesuai minat para siswa.

Berdasarkan hasil observasi yang dilakukan di SMP Muhammadiyah 15 Lamongan pada bulan Januari 2018 khususnya pada kelas VIII ditemukan bahwa media pembelajaran yang tersedia di dalam kelas rata-rata sudah menggunakan LCD, pada saat pembelajaran guru masih menjelaskan materi dengan buku seadanya tanpa menggunakan fasilitas yang tersedia, ada pula guru yang sudah menggunakan slide powerpoint, berdasarakan wawancara dengan salah satu guru IPS, Guru menggap buku dan slide powerpoint merupakan media yag paling mudah dalam penggunaanya, Guru pun juga merasa bahwa media yang digunakan masih belum dapat meningkatkan motivasi siswa, hal ini dirasakan ketika guru mengajar di kelas, masih dijumpai adanya siswa yang mengantuk saat guru menjelaskan materi dan partisipasi siswa di kelas yang masih rendah.Guru tersebut juga memaparkan bahwa saat ini pihak sekolah memang belum menyediakan maupun mengembangkan media pembelajaran yang benar-benar sesuai dengan kondisi siswa melainkan lebih ke kreativitas guru masingmasing dalam mengemas materi dengan menggunakan media pembelajaran di kelas.

Berdasarkan angket mengenai pendapat siswa kelas VIII tentang mata pelajaran IPS dan media pembelajaran, sebanyak $71 \%$ atau 10 siswa menganggap bahwa mata pelajaran IPS merupakan mata pelajaran yang sulit. Alasan menjawab sulit dikarenakan katakata dalam IPS sulit dipahami dan banyak yang harus dihafalkan. Sebanyak 39\% atau 15 siswa merasa jenuh dengan penggunaan media buku dan slide powerpoint secara terus-menerus. Sebanyak $26 \%$ atau 10 siswa mengaku kurang termotivasi untuk belajar IPS dengan penggunaan media pembelajaran yang masih bersifat monoton.

Dari paparan di atas peneliti mengajukan salah satu dari sekian media pembelajaran yaitu media ular tangga dalam menunjang kreativitas dan juga inovasi dalam pembelajaran siswa kelas VIII SMP Muhammadiyah 15 Lamongan dalam materi IPS. Media ular tangga termasuk media visual karena melibatkan indera penglihatan dalam menggunakan media tersebut dan disebut media grafik karena media ular tangga disajikan dalam bentuk gambar. Permainan ular tangga merupakan salah satu jenis permainan yang sering dimainkan oleh anak-anak.

Ular tangga adalah permainan yang menggunakan dadu untuk menentukan berapa langkah yang harus dijalani bidak. Permainan ini masuk dalam kategori "board game" atau permainan papan sejenis dengan permainan monopoli, halma, ludo, dan sebagainya. Papan berupa gambar petak-petak yang terdiri dari 10 baris dan 10 kolom dengan nomor 1-100, serta bergambar ular dan tangga (Husna, M. 2009). Pengertian tersebut sesuai dengan pengertian dari Rahman dalam bahwa permainan ular tangga merupakan salah satu permainan papan yang ringan dan cukup populer di Indonesia selain permainan papan lain seperti monopoli, ludo, dam, dan halma. Pendapat tersebut didukung oleh pendapat Satya yang menyatakan bahwa permainan ular tangga bersifat ringan, sederhana, mendidik, menghibur, dan sangat interaktif jika dimainkan bersamasama. Permainan ular tangga ini ringan jika dibawa, mudah dimengerti karena peraturan permainannya sederhana, mendidik, dan menghibur anak-anak dengan cara yang positif (Faizal, 2010).

Ular tangga termasuk media permainan yang tidak lepas dari adanya gambar atau foto yang ada di papan permainan ular tangga, seperti gambar ular dan tangga, maupun gambar lain sesuai tema ular tangga. Gambar atau foto berfungsi untuk menyampaikan pesan melalui gambar yang menyangkut indera penglihatan sehingga dapat menarik perhatian, mengilustrasikan fakta atau informasi. Sehubungan dengan hal 
tersebut, gambar atau foto termasuk media berbasis visual representasi. Hal itu sesuai dengan pendapat Cecep Kustandi dan Bambang Sutjipto, bahwa media berbentuk visual dapat berupa gambar representasi seperti gambar lukisan atau foto yang menunjukkan bagaimana tampaknya suatu benda (Kustandi, 2011).

Media pembelajaran permainan seperti ular tangga IPS dikembangkan karena memiliki keunggulan dibandingkan media pembelajaran yang lain, yaitu (1) permainan adalah sesuatu yang menyenangkan untuk dilakukan dan menghibur, (2) permainan memungkinkan adanya partisipasi aktif siswa untuk belajar, (3) permainan dapat memberikan umpan balik langsung, (4) permainan memungkinkan penerapan konsep ataupun peran-peran ke dalam situasi peranan yang sebenarnya di masyarakat, (5) permainan bersifat luwes, (5) permainan dapat dengan mudah dibuat dan diperbanyak (Sadiman dkk., 2011).

Permainan yang dimainkan oleh dua orang atau lebih ini dapat melatih anak untuk berkompetisi. Selain itu, permainan ular tangga dapat melatih anak untuk bekerja sama serta melatih anak untuk bertindak sportif, (Zuhdi, 2010). Menurut Yudha bahwa permainan ular tangga merupakan jensi permainan kompetisi yang diarahkan pada kemampuan kerja sama dan sportivitas sehingga mampu merekayasa pengalaman sosial dan moral anak. Seperti halnya media yang lain, maka media ular tangga juga memiliki beberapa kelebihan, antara lain: a) Gambar bidak yang dipindah-pindahkan dapat menarik perhatian siswa, siswa dapat berperan aktif untuk memindahkan objek tersebut. Hal ini menunjukkan bahwa siswa terlibat tidak hanya secara intelektual namun juga fisik. b) Pembelajaran dapat di atur sesuai dengan kebutuhan yaitu individual maupaun secara kelompok. Dalam pembelajaran berkelompok siswa dapat bekerja sama dalam menyelesaikan tugas yang diberikan guru.

Dalam penerapannya, media ular tangga dipadukan dengan model pembelajaran tematik. Model pembelajaran tematik adalah model pembelajaran terpadu yang menggunakan pendekatan tematik yang melibatkan beberapa mata pelajaran utnuk memberikan pengalaman bermakna kepada siswa. Dalam pembelajaran tematik, siswa akan memahami konsep-konsep yang mereka pelajari melalui pengalaman langsung dan menghubungkannya dengan konsep lain yang telah dipahaminya.

Media pembelajaran ular tangga membutuhkan siswa untuk langsung menerapkan dalam kelas, media pembelajarn ular tangga bisa menggunakan kertas karton atau banner yang sudah didesain untuk pembelajaran yang berisi tentang materi dalam selesai satu bab materi, dan disusun beberapa kelompok, setiap kelompok yang bisa menjawab pertanyaan dalam setiap kotak ular tangga itu yang dianggap pemenang. Berangkat dari paparan di atas peneliti mengajukan judul penelitian yaitu "Pengembangan Media Pembelajaran Ular Tangga Untuk Meningkatkan Motivasi Belajarpada Mata Pelajaran IPS "Perubahan Masyarakat Indonesia Pada Masa Penjajahan Dan Tumbuhnya Semangat Kebangsaan" Kelas VIII Di SMP Muhammadiyah 15 Lamongan"

\section{METODE}

Metode penelitian yang digunakan yaitu pengembangan ADDIE dengan 5 tahapan lima tahapan dalam model ADDIE (Analysis, Design, Development, Implementation, Evaluation). Tahapan-tahapan tersebut antara lain (Mulyatiningsih, 202:):

1. Tahap Analisis (Analysis) meliputi ; analisis kurikulum, analisis kebutuhan siswa dan analisis kompetensi. 
2. Tahap Desain (Design) meliputi; Perancangan Desain Produk, Penyusunan Aturan Permainan, Soal, Materi, dan Jawaban serta Menyusun Instrumen Penilain Produk

3. Tahap Pengembangan (Development) meliputi; Pembuatan Produk, Validasi, Revisi I.

4. Tahap Implementasi (Implementasi) meliputi

Desain uji coba produk dapat dilakukan dengan eksperimen, yaitu membandingkan keadaan sebelum dan sesudah memakai metode mengajar baru (before-after) atau dengan membandingkan kelompok yang tetap berbasis metode lama. Dalam hal ini ada kelompok eksperimen dan kelompok-kelompok kontrol. Disini kelompok eksperimen adalah kelompok yang akan diajar dengan metode mengajar baru, sedangkan kelompok yang berbasis metode mengajar lama disebut kelompok kontrol, (Sugiyono, 2015). Pada tahap implementasi ini, kegiatan yang dilakukan meliputi:

a. Uji coba kelompok kecil

Pada tahap ini produk produk diujicobakan kepada 10 - 15 siswa dari kelas VIII SMP Muhammadiyah 15 Lamongan. Pada tahap ini juga dibagikan angket untuk mengetahui penilaian siswa mengenai produk.

\section{Desain Eksperimen dengan Kelompok Kontrol, (Pretest-postest contol group desain)}



Jadi :

$\mathrm{O}_{1}$ : Nilai awal kelompok eksperimen

$\mathrm{O}_{2}$ : Prestasi kelompok eksperimen setelah diajar dengan metode baru

$\mathrm{O}_{3}$ : Nilai awal kelompok control

$\mathrm{O}_{4}$ : Prestasi kelompok eksperimen setelah diajar dengan metode lama

b. Revisi II (jika diperlukan)

Revisi tahap II dilakukan berdasarkan masukan dan saran darisiswa dari uji coba kelompok kecil. Namun, dalam revisi ini akan mempertimbangkan masukan dan saran dari validator sebelumnyaagar tidak bertentangan dengan perbaikan-perbaikan sebelumnya.

c. Uji coba lapangan

Pada tahap ini produk produk diujicobakan kepada $>20$ siswa(satu kelas) dari kelas kelas VIII SMP Muhammadiyah 15 Lamongan. Pada tahapini juga dibagikan angket untuk mengetahui penilaian siswa mengenaiproduk yang dikembangkan.

d. Revisi III (jika diperlukan)

Revisi tahap III dilakukan berdasarkan masukan dan saran darisiswa. Namun, dalam revisi ini akan mempertimbangkan masukan dan saran dari validator sebelumnya agar tidak bertentangan dengan perbaikan-perbaikan sebelumnya.

5. Tahap Evaluasi (Evaluation)

Pada tahap ini peneliti melakukan evaluasi untuk mengukur ketercapaian tujuan pengembangan produk media pembelajaran Ular Tangga. Evaluasi ini digunakan 
untuk mengetahui keefektifan pengembangan media Ular Tangga dalam meningkatkan motivasi belajar siswa. Pada tahap ini siswa diberi angket motivasi belajar sebelum dan sesudah pembelajaran dengan menggunakan media Ular Tangga kemudian angket tersebut dianalisis.

\section{HASIL DAN PEMBAHASAN Hasil}

\section{Pengembangan media pembelajaran Ular Tangga matapelajaran IPS siswa kelas VIII SMP Muhammadiyah 15 Lamongan.}

Pengembangan media pembelajaran media ular tangga didasarkan pada analisis kebutuhan bahwa belum tersedianya media pembelajaran ular tangga serta atas dasar analisis media ajaar IPS yang digunakan pada pembelajaran IPS kelas VIII SMP Muhammadiyah 15 lamongan. Media pembelajaran ular tangga diekmbangan menggunkan model desain pengembangan ADDIE ini melalui serangkaian tahap pengembangan yyang sistematis yakni tahap (analysis), tahap (design), tahap (development), tahap (implementation), dan tahap (evalution). Pengembangan media pembelajaran ular tangga ini memiliki spesifikasi sebagai berikut:

a. Wujud fisik dari produk yang dihasilkan dalan pengembangan ini adalah media cetak berupa media pembelajaran ular tangga (material printed).

b. Media pembelajaran ular tabgga ini dikembangan dengan menggunakan jiwa nasionalsime, kebangsaan, dan motivasi islami.

c. Bentuk fisik media pembelajaran ular tangga ini berupa media cetak yang disusun dengan menggunakan variasi tata letak, pilihan warna, variasi gambar, variasi huruf yang sesuai dengan ketentuan penulisan bahan ajar menurut Badan standart Nasional Pendidikan (BSNP) agar sesuai dengan karakter peserta didik, sehingga media pembelajaran ular tangga ini menjadi menarik untuk dijadikan bahan ajar.

Produk pengembangan bahan ajar berupa media pembelajaran ular tangga dilakukan analisis yang meliputi tiga aspek materi/isi, aspek desain, dan aspek bahasa. Berikut deskripsi media pembelajaran ular tangga yang dikembangkan dari ketiga aspek.

\section{1) Identitas Produk}

$\begin{array}{ll}\text { Bentuk } & \text { : Bahan Cetak (material printed) } \\ \text { Judul } & \text { : Media Pembelajaran Ular Tangga IPS } \\ \text { Sasaran } & \text { : Siswa kelas VIII SMP Muhammadiyah 15 Lamongan } \\ \text { Nama Pembuat } & \text { : Dewi Ayu Imaliyah } \\ \text { Cetakan } & : \text { Pertama } \\ \text { Ukuran banner } & : 1 \mathrm{~m} \times 1,5 \mathrm{~m}\end{array}$

2) Kajian Aspek Desain

a) Tipe Font

Tipe font yang digunakan pada media pembelajaran ular tangga bervariasi dengan pertimbangan penggunaan media pembelajaran ular tangga untuk meningkatkan antusias siswa dalam melakukan permainan, dan disarankan oleh ahli materi.

b) Ukuran Font

Ukuran font yang digunakan pada media pembelajaran ular tangga ini disesuaikan dengan bentuk media pembelajaran, dari media ular tangga, kartu soal, motivasi, soal, materi dan kartu point. Karena mempertimbangkan kemudahan siswa untuk memahami media pembelajaran ular tangga. 


\section{c) Warna (colour)}

Warna merupakan unsur visual yang penting dalam penulisan bahan ajar, namun penggunaannya harus berhati - hati untuk memperoleh hasil yang baik, begitupun dengan penggunaan warna pada media pembelajaran ular tangga ini berusaha menggambarkan makna dari medai dan memperluas gender pengguna.

\section{d) Gambar}

Dengan adanya gambar pada pembelajaran ular tangga ini diharapkan mampu menvisualisasikan tentang apa yang dipelajari pada setiap item, sehingga mempermudah siswa dalam memahami materi.

3) Kajian Aspek Desain dan Materi .

Kajian tentang aspek desain materi pada media ular tangga sebagai berikut.

\section{a) Boardgame Ular Tangga}

Boardgame disusun secara menarik mungkin, sehingga siswa memiliki keinginan dan ketertarikan untuk mempermainkan media pembelajaran ular tangga ini, board game ini teridiri dari ular dan tangga, sebagai mediator dari permainan ini, didalamnya ada macam - macam gambar seperti, bendera, tank, pistol, teks, setiap gambar memiliki kegunaan tersendiri untuk memberikan pemngembangan dalam permainan dalam pembelajaran

\section{b) Petunjuk Permainan}

Petunjuk permainan ini disusun dengan warna yang sesuai dengan teks dan bentuk font untuk memudahkan siswa untuk memahmi dan ada point - point didalam petunjuk permainan, petunjuk permainan digunakan untuk memandu setiap permainan, disetiap point didalam petunjuk permainan memiliki kegunaan masing masing dan siswa dapat membaca dengan seksama.

Untuk mengetahui media pembelajran ular tangga tersebut valid dan praktis dilakukan uji coba dalam hal ini adalah expert reviews. Validasi ini dilakukan oleh pakar berfokus pada tiga karakteristik utama yaitu materi/isi IPS, desain media produk, dan pembelajaran IPS. Validasi ini dilakukan untuk menilai rancangan produk yang tellah dikemabangkan. Setelah media pembelajaran ular tangga dilakukan validasi, kemudian dilakukan analisis data kuantitatif yaitu jumlah skor angket dan data kualitatif yaitu komentar dan saran dari para ahli. Dari hasil validasi oleh ahli materi/isi mendaptkan skor $95 \%$ yang berarti valid, ahli desain produk mendapatkan skor $75 \%$ yang berarti cukup valid.

Pada proses pengembangan media pembelajaran ular tangga in. Peneliti melakukan uji coba kepada siswa sebagai pembelajaran yang dimaksudkan untuk mengetahui respon siswa terhadap produk yang dikembangkan. Peneliti melakukan uji coba lapangan dilakukan kepada 15 siswa dalam kelompok eksperimen kelas VIII SMP Muhammadiyah 15 Lamongan. Prototype yang dilakukan uji coba lapangan mendapat presentase $87 \%$ sehingga dikonverensikan berada pada tingkat kualifikasi valid. Media pembelajaran ular tangga dapat dilakukan oleh seluruh siswa dikelas dengan secara langsung bermain di kelas.

Kelayakan media pembelajaran Ular Tangga mata pelajaran IPS pada siswa kelas VIII SMP Muhammadiyah 15 Lamongan berdasarkan penilaian dari ahli materi dan ahli media.

Kelayakan media pembelajaran diperoleh berdasarkan penilaian ahli materi (dosen IPS) dan ahli media (dosen FITK ). Penjelasan selengkapnya sebagai berikut. 


\section{a. Ahli Materi}

Ahli materi menilai kelayakan media ditinjau dari aspek pembelajaran. Hasil validasi dari ahli materi secara lengkap ditunjukkan pada bab empat halaman. Penilaian kelayakan aspek pembelajaran terdiri dari 20 butir pernyataan. Dari 20 butir pernyataan, terdapat 15 butir yang memperoleh rerata skor tertinggi dengan kategori Sangat Layak yaitu kesesuaian materi dengan kompetensi dasar, kesesuaian materi dengan indikator, kesesuaian materi dengan tujuan pembelajaran, penumbuhan motivasi belajar, aktualitas materi yang disajikan, tingkat kesulitan soal sesuai materi,kedalaman soal sesuai materi, kemudahan pembelajaran untuk dipahami, bahasa soal yang mudah dipahami, keruntutan penyajian soal, ketepatan penggunaan istilah dan pernyataan dan ketepatan kunci jawaban dengan soal. Penilaian terhadap 8 butir pernyataan lainnya adalah Layak. Dimana bisa dilihat rekapitulasi pemberian penilaian dari ahli materi dari dosen dari guru, dari dosen adalah $95 \%$ sangat menarik dapat digunakan tanpa revisi. Dengan demikian media ular tangga layak digunakan sebagai media pembelajaran siswa SMP.

\section{b. Ahli Media}

Ahli media menilai kelayakan media ditinjau dari aspek rekayasa media dan komunikasi visual. Hasil validasi dari ahli media secara lengkap ditunjukkan pada bab IV. Kelayakan aspek rekayasa media dari 21 pernyataan termasuk kategori layak. Penilaian dari dosen adalah $75 \%$ cukup menarik tingkat validitas dapat digunakan dengan revisi kecil. Dengan demikian media ular tangga dalam penilaian ahli media layak digunakan sebagai media pembelajaran siswa SMP.

\section{Pembahasan}

Setelah peneliti melakukan pejelasan kepada guru dan guru mengaplikasikan kepada dua kelas tersebut, peneliti melakukan kegiatan post-test untuk mengetahui tingkat kemajuan yang telah dicapai oleh siswa dalam suatu kurun waktu proses belajar selama 3 kali pertemuan. Pembelajarn dengan menggunakan media pembelajaran ular tangga yang dikembangkan memberikan pengaruh positif terhadap nilai hasil belajar siswa. Pencapaian keefektifan media pembelajaran IPS dengan media pembelajaran ular tangga ditunjukkan dengan adanya peningkatan hasil belajar iswa pada kelas eksperimen lebih baik daripada kelas kontrol.

Pada kelompok eksperimen ukuran minimal sampel yang diterima adalah 15 subjek per kelompok. Sehingga pada penelitian pengembangan ini peneliti hanya mengambil ukuran siswa smp minimal sampel yaitu 15 responden pada kelompok kontrol dan 15 responden pada kelompok eksperimen. Pada kelompok kontrol pembelajaran dilakukan tanpa media pembelajaran ular tangga. Sedangkan pada kelompok eksperimen, pembelajaran dilakaukan menggunakan media pembelajaran media ular tangga.

Dari hasil pre-test ini peneliti dapat menganalisis kelemahan pengetahuan siswa dalam konsep perkembangan siswa dala kelas. Hal ini sesuai dengan yang dijelaskan Dimyati dan Mujiono yakni halil belajar pada akhirnya difungsikan dan ditunjukkan untuk mendiagnosis kelemahan dan keunggulan siswa beserta sebab - sebabnya. Berdasarkan diagnosis inilah guru mengadakan pengembangan kegiatan pembelajaran untuk meningkatkan hasil belajar siswa (Husein, 1999 dan Dimyati, 2006).

Peningkatkan hasil belajar diperoleh dari hasil post-test yang diuji dengan independent samples $t$-test dinyatakan bahwa nilai kemampuan kedua kelas mengenai perubahan masyarakat Indonesia pada masa penjajahan dan tumbuhnya semangat 
kebangsaan adalah dapat dilihat dari hasil penghitungan dalam bab empat. Hal ini dapat disimpulkan terdapat perbedaan hasil belajar siswa yang memperoleh pembelajaran dengan menggunakan media pembelajaran ular tangga dari pada hasil belajar siswa yang memperoleh pembelajaran tanpa menggunkan media pembelajaran ular tangga.

Selain itu media pembelajaran media ular tangga pada materi perubahan masyarakat Indonesia pada masa penjajahan dan tumbuhnya semangat kebangsaan secara efektif dapat meningkatkan hasil belajar siswa kelas VIII SMP Muhammadiyah 15 Lamongan. Dengan melihat rata - rata kelas kontrol lebih kecil dibandingkan dengan kelas eksperimen pada post-test yaitu $1262<1355$.

Adanya kestabilan, peningkatan, dan penurunan hasil belajar tersebut dapat menunjukkan disebabkan oleh beberapa faktor. Hal tersebut membuktikan jika suatu keberhasilan proses pembelajaran membutuhkan dukungan dan mngaitkan beberapa aspek. Ada dua faktor yang dapat mempengaruhi hasil belajar yaitu faktor internal, faktor rohani atau psikologis, dan faktor eksternal. Faktor internal yakni faktor dari dalam siswa seperti keadaan/kondisi jasmani (aspek fisiologis) dan rohani (aspek psikologi) siswa. Faktor eksternal yaitu faktor dari luar pengamatan, faktor yang paling berpengaruh terdapat hasil belajar siswa adalah faktor internal yaitu dari aspek psikologi siswa.

Salah satu aspek psikologi siswa adalah gaya belajar siswa. Gaya belajar adalah cara yang lebih kita sukai dalam melakukan kegiatan berfikir, memproses, dan mengerti suatu informasi (Gunawan, 2004). Hasil riset menunjukkan bahwa murid yang belajar dengan menggunkan gaya belajar yang dominan, saat mengerjakan tes akan mencapai nilai yang jauh lebih tinggi dibandingkan bila mereka belajar dengan cara yang tidak sejalan dengan gaya belajar mereka.

Terdapat macam - macam gaya belajar, antara lain gaya belajar auditori, gaya belajar visual, gaya belajar kinestetik, gaya belajar global, dan gaya belajar abalitik. Pada proses penelitian ini, proses pembelajaran di desain menggunakan media pembelajaran media ular tangga mendukung cara belajar gaya auditori dan gaya belajar secara langsung atau bisa disebut siswa ikut serta dan aktif dalam pembelajaran.

Perhitungan uji T-test berkorelasi dengan tingkat kepercayaan 95\%. Peneliti menghasilkan $t_{\text {hitung }}=6,521$ sedangkan $t_{\text {tabel }}=2,145$ karena $t_{\text {hitung }}>t_{\text {tabel }}$ maka $H_{0}$ ditolok artinya terdapat perbedaan signifikan peningkatan hasil belajar IPS siswa kelas VIII E pada pokok bahasan perubahan masyarakat Indonesia pada masa penjajahan dan tumbuhnya semangat kebangsaan yang menggunakan media ular tangga dengan hasil belajar IPS siswa kelas VIII D yang tidak menggunakan media pembelajaran ular tangga di SMP Muhammadiyah 15 Lamongan.

\section{KESIMPULAN}

1. Pengembangan media pembelajaran media ular tangga didasarkan pada analisis kebutuhan bahwa belum tersedianya media pembelajaran ular tangga.

2. Kelayakan media pembelajaran diperoleh berdasarkan penilaian ahli materi (dosen IPS) dan ahli media (dosen FITK ) dinilai layak untuk digunakan.

3. Pembelajaran dengan menggunakan media pembelajaran ular tangga yang dikembangkan memberikan pengaruh positif terhadap nilai hasil belajar siswa.

\section{DAFTAR PUSTAKA}

Azhar, Arsyad. (2002). Media Pembelajaran. Jakarta : Rajawali Pers. Dimyati dan Mudjiono. (2006). Belajar dan Pembelajaran. Jakarta: Rineka Cipta 
Faizal, Rahman. (2010). Ular Tangga. Makalah Politeknik. Yogyakarta: tidak diterbitkan

Gunawan, Adi. (2004). Genius Learning Strategy Petunjuk Proses Mengajar. Jakarta: PT Gramedia Pustaka Utama

Husein, Umar. (1999). Riset Sumber Daya Manusia Dalam Organisasi. Jakarta: PT.Gramedia Pustaka Utama

Husna M. (2009). 100+ Permainan Tradisional Indonesia untuk Kreativitas, Ketangkasan, dan Keakraban. Yogyakarta: Penerbit Andi

Kustandi, Cecep \& Bambang Sutjipto. (2011). Media Pembelajaran Manual dan Digital. (Bogor: Penerbit Ghalia Indonesia.

Mulyatiningsih, Endang. (2012). Metode Penelitian Terapan Bidang Pendidikan. Bandung : Alfabeta.

Rusman. (2012). Belajar dan Pembelajaran Berbasis Komputer. Bandung : Alfabeta.

S, Arief Sadiman, dkk. (2011). Media Pendidikan dan Proses Belajar Mengajar. Jakarta : PT Raja Grafindo Persada.

Sugiono. (2015). Metode Penelitian Pendidikan Pendekatan Kuantitatif, Kualitatif, dan $R \& D$. Bandung : Alfabeta.

Zuhdi, Ulhaq, dkk. (2010). Pengembangan Perangkat Media Pembelajaran Ular Tangga Digital Untuk Meningkatkan Penguasaan Kosakata Bahasa Inggris (Vocabulary) pada Mahasiswa S-1 PGSD. (Jurnal Pendidikan Wacana Pendidikan Sekolah Dasar Tahun). 